\title{
THE PHENOL RED CLEARANCE IN NORMAL MAN
}

\author{
By WILLIAM GOLDRING, ROBERT W. CLARKE AND HOMER W. SMITH \\ (From the Departments of Medicine and Physiology, New York University College of Medicine \\ and the Third (New York University) Medical Division, Bellevue Hospital, \\ New York City)
}

(Received for publication December 9, 1935)

Although phenol red, introduced by Rowntree and Geraghty (6) in 1912, has been widely used in man as an empirical renal function test, the excretion of this substance relative to its concentration in the plasma has been examined in only one instance. MacKay (1930) injected one gram intravenously and calculated the Addis excretory ratio in three successive periods when the plasma level was 5.80, 3.90 and $3.25 \mathrm{mgm}$. per cent, and obtained values about three times the simultaneous values for urea.

That phenol red is excreted in part by tubular secretion in the dog is indicated by abundant evidence; this evidence has been reviewed recently by Shannon (1935), whose additional observations indicate that the greater portion of the dye must be excreted by tubular activity, and that this secreted fraction diminishes in a regular manner as the plasma level of the dye is increased above 2 to $3 \mathrm{mgm}$. per cent. The present report concerns observations on the simultaneous phenol red and inulin clearances in normal man. (For data relative to the excretion of inulin by man see Shannon and Smith (1935).)

\section{EXPERIMENTAL PROCEDURE}

These observations were made on volunteer convalescent patients from the wards of the Medical Service of the Third (New York University) Medical Division of Bellevue Hospital who gave no history or other evidence of impaired renal function. The observations were made in the morning without breakfast, and with as close simulation of basal conditions as possible. Inulin (dahlia), prepared as described by Shannon and Smith (1935), was given intravenously, the time at the end of the infusion being noted as the zero minute of the experiment. The phenol red, prepared by Messrs. Hynson, Westcott and Dunning as a sterile 10 per cent solution of the sodium salt, was injected intravenously in doses varying from
0.3 to 3 grams. Urine formation was maintained at rates above $1.0 \mathrm{cc}$. per. minute by the administration of two to three liters of water during the night and several glasses of water up to $60 \mathrm{~min}$ utes before the beginning of the inulin infusion.

In the shorter series of observations 40 grams of inulin were administered, followed at once by the phenol red. The bladder was emptied by catheter at about 20 minutes, the catheter being left in place during the successive urine collection periods. Twenty cubic centimeters of water were used to wash out the bladder at the end of each period, and complete emptying of the bladder was assured by introducing 3 successive 20 cc. portions of air. Blood samples were drawn at approximately the middle of the urine collection periods, which varied from 15 to 25 minutes, and were interpolated to the midpoint on a semilogarithmic chart.

The longer series of observations, involving multiple injections of the dye, are exemplified by the procedure on $\mathrm{L}$. $\mathrm{R}$. illustrated at the left in Figure 4 and described in the legend of that figure.

\section{CHEMICAL METHODS}

Immediate coagulation of the blood was prevented by the use of colorless heparin; the blood was centrifuged at once, and samples for the determination of inulin were precipitated immediately. Oxalate was added to the rest of the plasma, to preserve it for phenol red determination, and in some instances for ultrafiltration, in which cases the blood was drawn and centrifuged under oil. Urine samples were diluted at once to the expected inulin urine/plasma ratio and precipitated at the termination of the experiment.

Inulin was determined in both plasma and urine by acid hydrolysis $\left(0.1 \mathrm{~N} \mathrm{H}_{2} \mathrm{SO}_{4}\right)$ of the Somogyi (1931) copper sulphate-sodium tungstate filtrate, and the Folin (1929) sugar method. The fil- 
trate was treated with yeast to remove glucose prior to hydrolysis in all cases.

Total phenol red was determined colorimetrically, using an $\epsilon 74$ Wratten filter, after the addition of one drop of saturated $\mathrm{Na}_{2} \mathrm{CO}_{3}$ solution to 2 cc. of plasma diluted with 0.9 per cent $\mathrm{NaCl}$ to about $1.0 \mathrm{mgm}$. per cent phenol red. The urines were similarly diluted with water. Plasma blanks at concentrations of dye ranging from 0.0 to $1.0 \mathrm{mgm}$. per cent were determined for each individual by adding known quantities of phenol red in minimal quantities of water to a sample of plasma drawn just prior to the inulin infusion, successive dilutions being made by the addition of plasma to obtain about $1.0,0.75,0.50$ and 0.25 mgm. per cent of dye. These blanks varied from 0.05 to $0.30 \mathrm{mgm}$. per cent, and they are not invariably additive, as observed by Shannon (1935) in the dog. The fraction of free phenol red in the plasma was determined by ultrafiltration through collodion membranes at $37.5^{\circ} \mathrm{C}$., $40 \mathrm{~mm}$. $\mathrm{pCO}_{2}$, by the method described by Shannon (1935).

\section{Binding of phenol red by plasma proteins}

Before discussing the excretion of phenol red, reference should be made to the extent to which this dye is bound by plasma proteins in human blood. Grollman (1925) has shown that at constant $\mathrm{pH}$ the combination between the dye and plasma protein is a reversible one, following very closely the adsorption isotherm, $x / m=K c^{1 / n}$, where $x$ equals the milligrams of dye adsorbed on $m$ grams of adsorbent, and $c$ is the equilibrium concentration of free dye in mgm. per liter; $K$ and $1 / n$ are constants. This relationship is such that if the logarithms of the dye bound per $100 \mathrm{cc}$. of plasma (whereby $m$ in the above equation may be incorporated in $K$ to yield $K^{\prime}$ ) are plotted against the logarithms of the equilibrium concentration of free dye, a straight line results (Figure 1). The constants $K^{\prime}$ and $1 / n$ appear to vary in different species, $K^{\prime}$ depending, at least in part, upon the concentration of the plasma protein, while the exponent $1 / n$ appears to have a constant value for any one species. The data given in Figure 1 were obtained on several lots of plasma, each of which consisted of a pooled sample from three or more individuals. The heavy black triangles represent the results on a mixture of plasma from
13 individuals; because these data extend over the widest range of plasma values they have been used for the determination of the constant $1 / n$ (that is, the slope of the line in Figure 1). This determination was made by averaging the slopes between each point and every other point, and yielded the figure 0.943 . Inserting this value into the above equation, the constant $K^{\prime}$ was determined to be 0.55 , by solution for all the data. It may be noted that (at room temperature) $1 / n$ has a value in the serum of the pig, according to Grollman (1925) approximating 1.0; for human plasma at $37.5^{\circ} \mathrm{C}$. we obtain a value of 0.94 , and for dog plasma at $37.5^{\circ} \mathrm{C}$., Shannon (1935) obtained a value of 0.82 to 0.85 .

It follows from the equation that when the constant $1 / n$ is less than 1 , the relative fraction of free phenol red in a given sample of plasma is not constant, but increases as the total concentration of the dye is increased. Thus, reference to Figure 1 will show that at a concentration of 0.5 mgm. per cent, 19.8 per cent of the dye is free, whereas at a total concentration of $40.9 \mathrm{mgm}$. per cent, 24.3 per cent of the dye is free.

If the separation of glomerular fluid from the plasma is considered to be effected solely by filtration (a thesis controverted by no available evidence, and strongly supported by numerous observations on the frog and Necturus from Richards' laboratory), then it must be held that the content of dye in this glomerular filtrate cannot exceed the content of free dye in the plasma (as was found to be the case in the frog by Richards and Walker (1930)). During the process of filtration no change in concentration of free dye occurs, and therefore the dye that is bound by the plasma proteins remains undisturbed. This would mean that at a level of one milligram per cent in human plasma only 20 per cent of the dye is available for filtration. If the rate of glomerular filtration is $125 \mathrm{cc}$. per minute in man, the filtration clearance of dye (or that clearance effected solely by filtration) cannot exceed $25 \mathrm{cc}$. per minute.

The excretion of phenol red at low plasma levels

At plasma levels of the dye below one milligram per cent, the phenol red clearance in man is essentially constant and independent of the plasma con- 


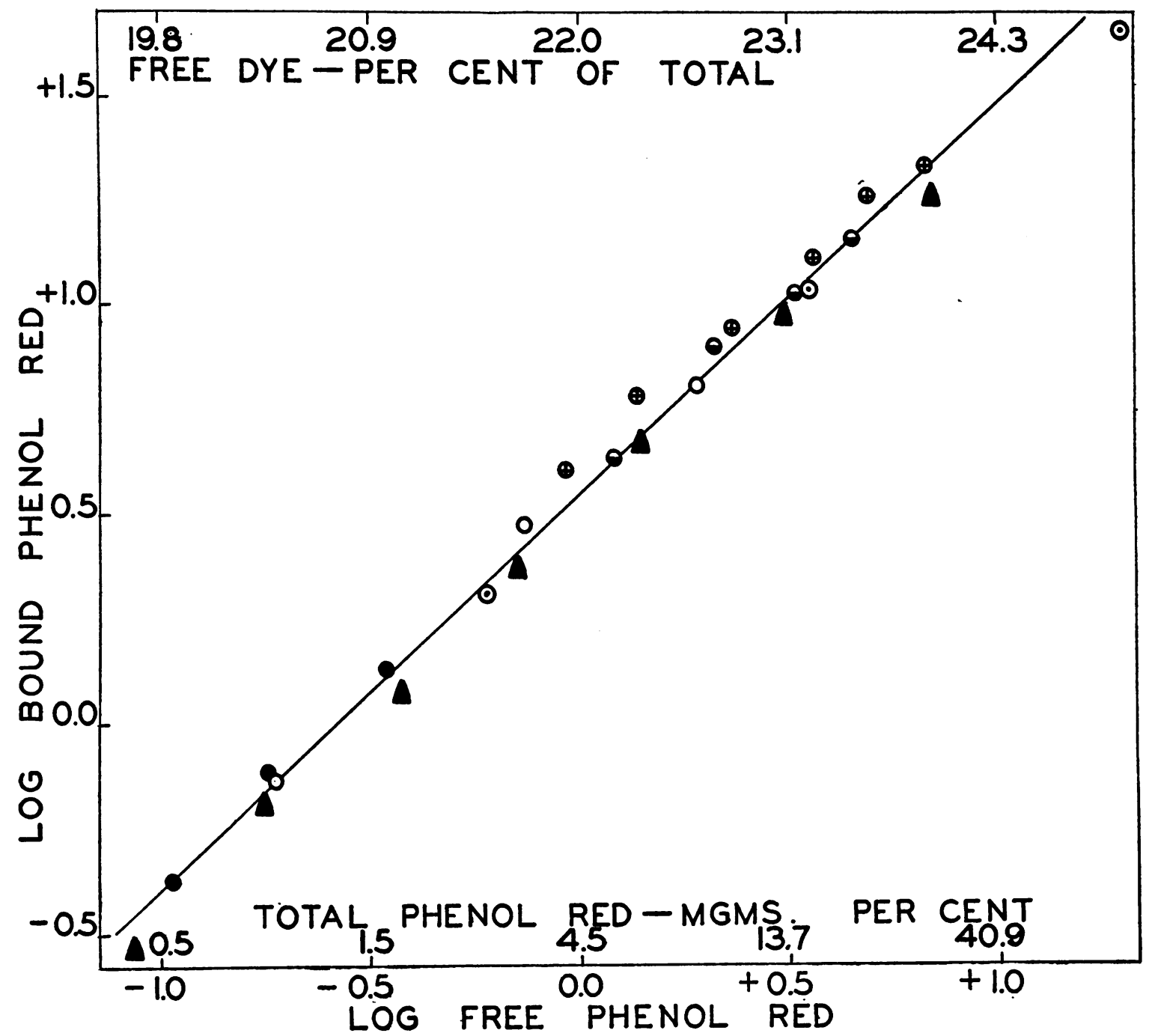

Fig. 1. Chart Showing the Relations between Bound Phenol Red (mgm. Bound per 100 cc. of Plasma) and the Equilibrium Concentration of Free Phenol Red (mgm. per 100 cc. of Protein Free Fluid) in Human Plasma.

The slope of the line is the exponent $1 / n$ in the equation given in the text, and being less than 1.0 is such that the per cent of free phenol red increases with increasing total concentration.

centration, having an average in these observations of 400 cc. per minute, when calculated upon the total dye in the plasma. A series of observations illustrating this point are given in Figure 2, each datum representing a single clearance determination, and the several symbols referring to different individuals. There can be little question that at these low plasma levels of phenol red a maximum clearance has been reached. Simultaneous inulin clearances were determined in nearly all instances recorded in Figure 2, and a summary of these and of the corresponding phenol red clearances is given in Table $I$. The inulin clearance (taken here as a measure of the rate of glomerular filtration (Shannon and Smith (1935)) averages in these observations $125 \mathrm{cc}$. per minute. The ratio of the simultaneous phenol red/inulin clearances averages 3.2. These facts indicate that a relatively great fraction of excreted phenol red is removed from the blood by some process other than filtration, and it must be assumed that this process consists primarily of the 
TABLE I

Summary of observations on inulin and phenol red clearances (at low plasma concentrations) in normal man

\begin{tabular}{|c|c|c|c|c|c|c|c|}
\hline Subject & $\begin{array}{l}\text { Sur- } \\
\text { face } \\
\text { area }\end{array}$ & $\begin{array}{l}\text { Num- } \\
\text { ber of } \\
\text { periods }\end{array}$ & Date & $\begin{array}{l}\text { Aver- } \\
\text { age } \\
\text { invilin } \\
\text { clear- } \\
\text { ance }\end{array}$ & $\begin{array}{l}\text { Inulin } \\
\text { clear- } \\
\text { ance } \\
\text { per } \\
\text { gq. } \mathrm{m} \text {. }\end{array}$ & $\begin{array}{l}\text { Aver- } \\
\text { age } \\
\text { dye } \\
\text { clear- } \\
\text { ance }\end{array}$ & $\frac{\text { Dye }}{\text { Inulin }}$ \\
\hline & $\begin{array}{l}\text { square } \\
\text { meters }\end{array}$ & & & $\begin{array}{l}\text { cc. per } \\
\text { minute }\end{array}$ & $\begin{array}{l}\text { cc. per } \\
\text { minute }\end{array}$ & $\begin{array}{l}\text { cc.per } \\
\text { minute }\end{array}$ & \\
\hline W.N. ه & 1.70 & $\begin{array}{l}\mathbf{3} \\
\mathbf{2} \\
\mathbf{5} \\
\mathbf{4} \\
\mathbf{3}\end{array}$ & $\begin{array}{l}\text { December 20, } 1934 \\
\text { December 20, } 1934 \\
\text { December 20, } 1924 \\
\text { December 27, } 1934 \\
\text { December 27, } 1934\end{array}$ & $\begin{array}{l}122 \\
122 \\
118 \\
123 \\
122\end{array}$ & 71.2 & $\begin{array}{r}383 \\
376\end{array}$ & $\begin{array}{l}3.14 \\
3.08\end{array}$ \\
\hline L.R. $\sigma^{7}$ & 1.69 & $\begin{array}{l}\mathbf{9} \\
\mathbf{7} \\
\mathbf{2} \\
\mathbf{3} \\
\mathbf{2} \\
\mathbf{2}\end{array}$ & $\begin{array}{lr}\text { February } & 4,1935 \\
\text { February } & 21,1935 \\
\text { February } & 21,1935 \\
\text { January } & 31,1935 \\
\text { February } & 14,1935 \\
\text { February } & 21,1935\end{array}$ & $\begin{array}{l}122 \\
128 \\
116 \\
125 \\
130 \\
145\end{array}$ & 75.8 & $\begin{array}{l}365 \\
410 \\
415 \\
437\end{array}$ & $\begin{array}{l}3.15 \\
3.28 \\
3.19 \\
3.01\end{array}$ \\
\hline T.K. व & 1.77 & 4 & January $\quad 8,1935$ & & & 403 & \\
\hline R.S. O' & 1.77 & $\begin{array}{l}6 \\
3\end{array}$ & $\begin{array}{ll}\text { January } & 10,1935 \\
\text { January } & 24,1935\end{array}$ & $\begin{array}{l}125 \\
122\end{array}$ & 70.0 & 387 & 3.17 \\
\hline F.D. O' & 1.56 & $\begin{array}{l}4 \\
4 \\
3\end{array}$ & $\begin{array}{ll}\text { January } & 14,1935 \\
\text { January } & 17,1935 \\
\text { January } & 24,1935\end{array}$ & $\begin{array}{l}141 \\
119 \\
117\end{array}$ & 80.8 & $\begin{array}{l}485 \\
405 \\
377\end{array}$ & $\begin{array}{l}3.44 \\
3.40 \\
3.22\end{array}$ \\
\hline & & & Average: & 125 & 74.5 & 404 & 3.21 \\
\hline
\end{tabular}

removal of this substance from the postglomerular blood by the tubules, which thereafter secrete it directly into the tubular lumen by a cellular process analagous to that operating in the aglomerular kidney. Actually, of $400 \mathrm{cc}$. of dye clearance, the dye contained in only $25 \mathrm{cc}$. of plasma (20 per cent of $125 \mathrm{cc}$.) can be accounted for by filtration, leaving that contained in $375 \mathrm{cc}$. to be explained otherwise. That is, of the total dye excreted, about 6 per cent is excreted by filtration and 95 per cent by tubular activity.

The above considerations apply to the standard phenol red test devised by Rowntree and Geraghty (1912) in which $6 \mathrm{mgm}$. of dye are injected intramuscularly. We have made a few observations on the blood concentration obtained by the intramuscular injections of 200 and $300 \mathrm{mgm}$. of this dye, and estimate that after a $6 \mathrm{mgm}$. dose the blood level would not average, if it actually reached, $0.01 \mathrm{mgm}$. per cent during the following two hours. At these plasma concentrations not over 17 per cent of the dye would be filterable, as calculated from the data in Figure 1 ; the filtration clearance would therefore be about $21 \mathrm{cc}$. per minute $(0.17 \times 125)$, leaving $380 \mathrm{cc}$. of plasma to be cleared by a secretion. That is, about 5 per cent of the total dye in this standard phenol red test would be excreted by filtration, and 95 per cent by secretion.

\section{The excretion of phenol red at high plasma levels}

When the concentration of dye in the plasma is raised to high levels by the injection either in single or multiple doses of larger quantities of dye, the absolute phenol red clearance, and therefore, the phenol red/inulin clearance ratio, is depressed in a uniform manner (Figures 3 and 4). The inulin clearance remains unaffected by the injection of the dye. This depression of the phenol red clearance appears to be a reversible process, as is shown by the two series of specially arranged observations illustrated in Figure 4. In these observations phenol red and inulin clearances were determined after the injection of a small quantity of dye; a moderate quantity of dye was then injected and the clearances again determined, and thereafter a large quantity of dye was injected and the clearances were determined both while the plasma level of dye was high and throughout the period of time when it was falling again to its original low level. The points representing the phenol red/inulin clearance ratio are superimposable, within the limits of error, upon the same curve, indicating the complete reversibility of the depression phenomena. One may assume that if the plasma level of dye were raised high enough, the phenol red clearance would be depressed asymptotically toward the filtration clearance of the dye.

The results so far described are entirely similar to those obtained by Shannon (1935) in his studies of the excretion of phenol red by the dog, and his discussion of this problem is in general applicable to man and need not be repeated here. It should be noted, however, that the capacity to secrete phenol red relative to the capacity to filter it (rate of glomerular filtration) is much more highly developed in man than in the dog, as is indicated by the fact that the phenol red/inulin clearance ratio has a value of 3.2 in man in comparison to 1.75 in the dog.

\section{Effect of plasma protein binding upon the maxi- mum dye clearance}

Returning to the excretion of phenol red at low plasma levels, one may visualize the essential steps 


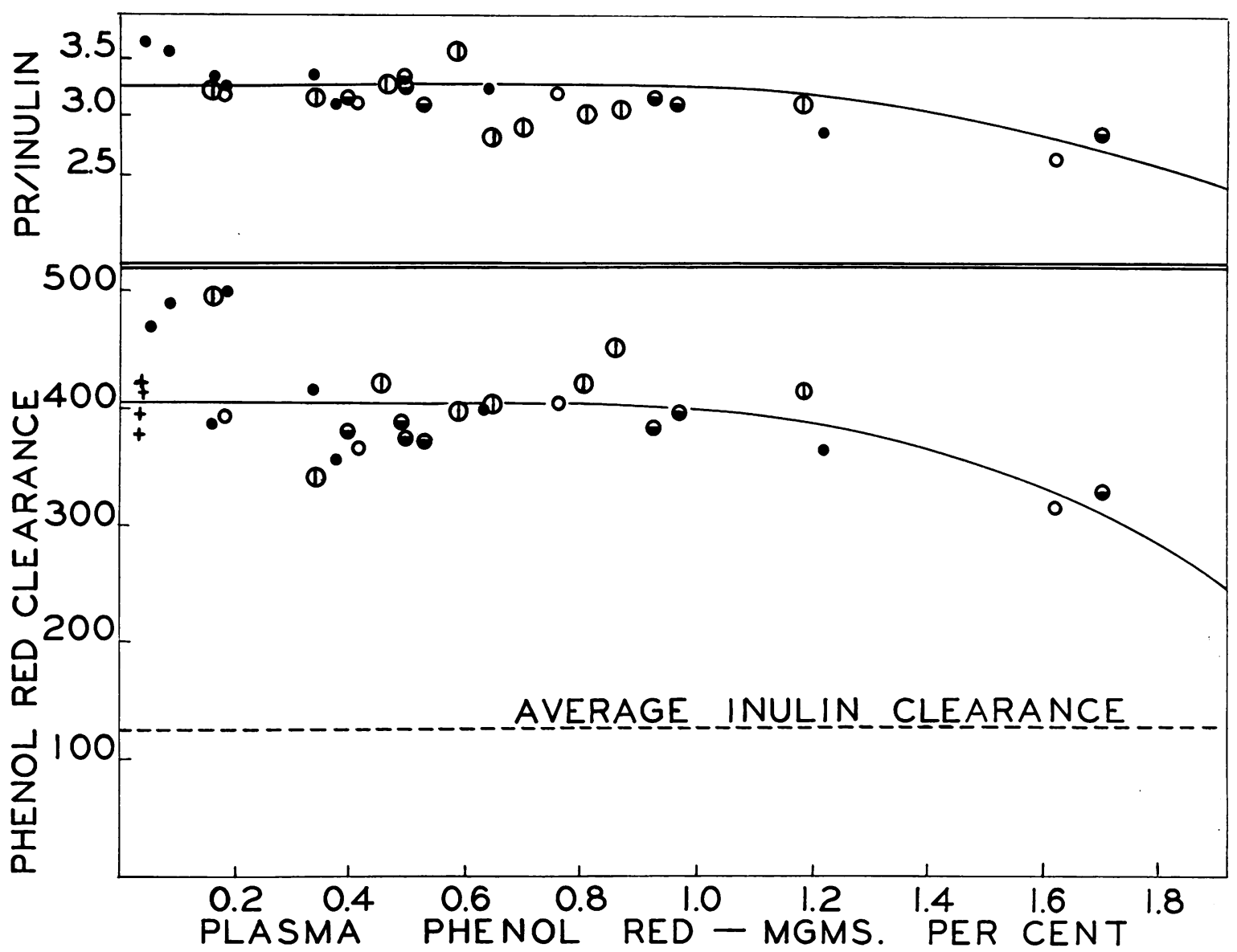

Fig. 2. The Phenol Red Clearance (Lower) and the Phenol Red/Inulin Clearance Ratio (Upper) in Normal Men in Relation to the Plasma Concentration of this Dye.

Below plasma concentrations of $1.0 \mathrm{mgm}$. per cent of dye the phenol red clearance is essentially constant, as is also the phenol red/inulin clearance ratio. Each datum refers to a single pair of simultaneous clearance determinations (with the exception of the crosses, where the phenol red clearance was determined alone), and the different symbols refer to different individuals. The average inulin clearance in these observations was $125 \mathrm{cc}$. per minute. There is a relatively wide scattering of the absolute values of the phenol red clearance due to variations in the renal activity of different individuals, and to errors in collection of urine. This scattering disappears in part when the phenol red/inulin clearance ratio is considered because errors involving both clearance determinations cancel out. This fact is illustrated by the standard deviation when calculated in terms of the per cent of the mean. In the absolute phenol red clearances this is 7.8 per cent while it is only 5.0 per cent in the phenol red/inulin ratio.

in the secretory process as involving, first, a nonspecific escape of the dye from the peritubular capillaries into the peritubular spaces and diffusion across the latter; and secondly, the specific absorption of the dye by the tubular cells and transfer to the tubular lumen. It is important to note that the passage of the dye from capillary to the periphery of the tubule cell must on general principles be considered to be effected by diffusion, the concentration of dye adjacent to the tubule being kept at a relatively low level by ab- sorption and secretion into the lumen. Even though one supposes that there is some circulation of interstitial fluid outside the capillary, it is probable that the movement of dye from the interior of the capillary to the tubule cell is effected largely by diffusion of dye molecules along a concentration gradient. This diffusion from capillary to tubule must lead to a reduction in the concentration of free dye in the plasma, and, therefore, to the dissociation of the reversible combination of dye and plasma protein, so that the orig- 


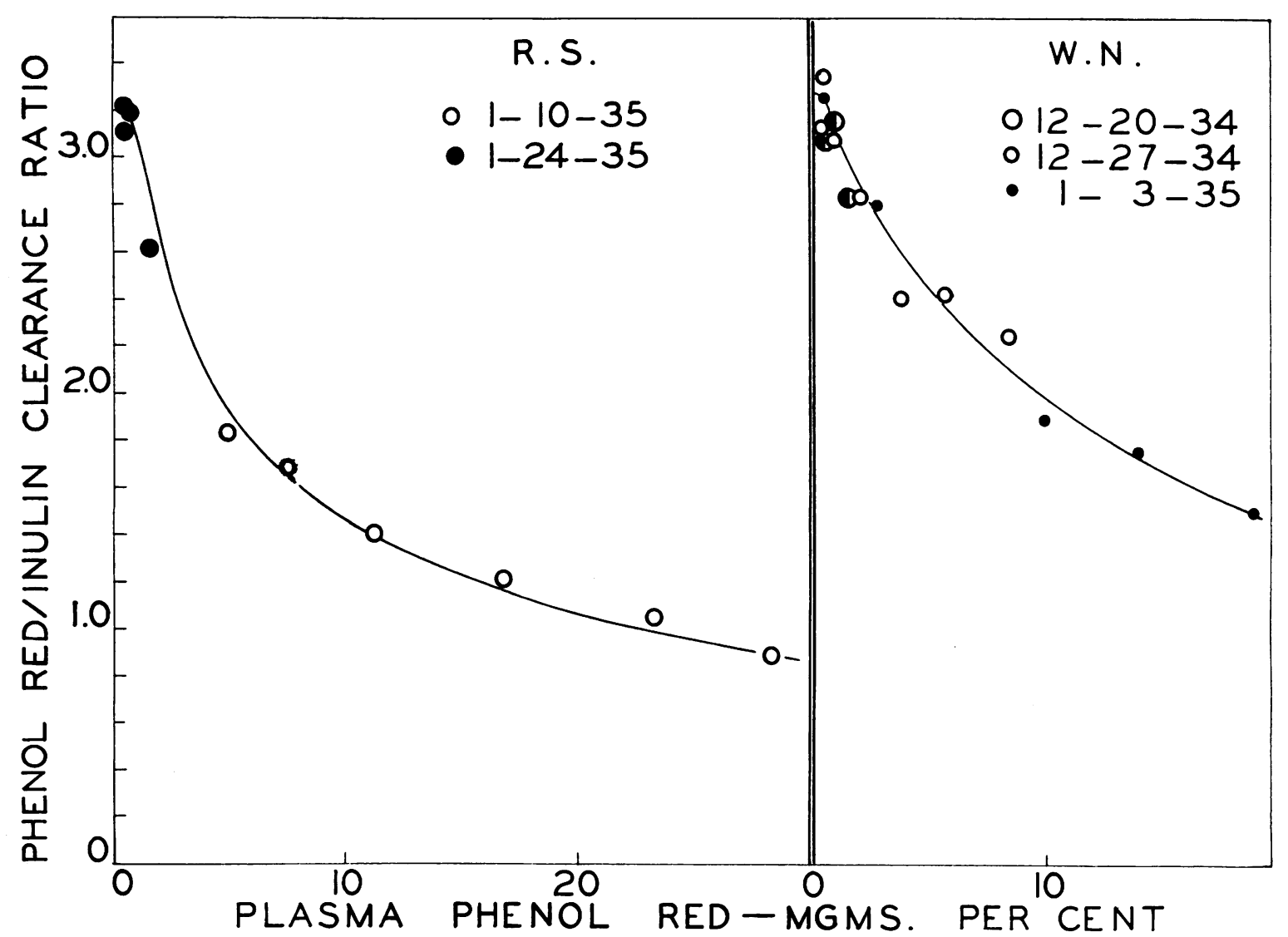

Fig. 3. Observations Showing the Variation in the Phenol Red/Inulin Clearance Ratio at Various Plasma Levels of the Dye.

The reduction in this ratio attending an increased concentration of the dye in the plasma is due to depression of the phenol red clearance, the inulin clearance remaining unchanged.

inally bound dye is made available for excretion as fast as free dye diffuses from the capillary.

Binding by plasma proteins would be equivalent, therefore, to creating a large reservoir of dye available for secretion, as though the virtual volume of the plasma containing a given concentration of free dye had been increased in proportion to the ratio, total dye/free dye. Comparing two dyes of the same diffusibility and same total concentration, that one which was bound to the greater extent would require the longer time to diffuse out of the capillaries, since the absolute rate of diffusion (mgm. per minute) would be proportionately less. If the secretory activity of the tubules was such as to effect almost complete clearance, however, the absolute differences in clearances of the two dyes might be, in respect to the total blood flow, relatively small. It is therefore impossible to state, on the basis of the present evidence, to what quantitative extent the binding of dye by the plasma proteins modifies the tubular clearance of phenol red.

\section{Whole blood phenol red clearance}

When phenol red is added to oxalated whole blood and the latter is centrifuged immediately, about 95 per cent of the added phenol red can be recovered from the plasma, when the plasma volume is calculated upon the hematocrit as ordinarily determined. The 5 per cent lost to the cells is lost within the first minute or two, and may perhaps be attributed to adsorption. That actual penetration into the cells is slow is indicated by the fact that it becomes evident in vitro only after 30 minutes. This impermeability of red cells to phenol red is also true in the dog (Marshall (1931)).

Because phenol red is present only in the 


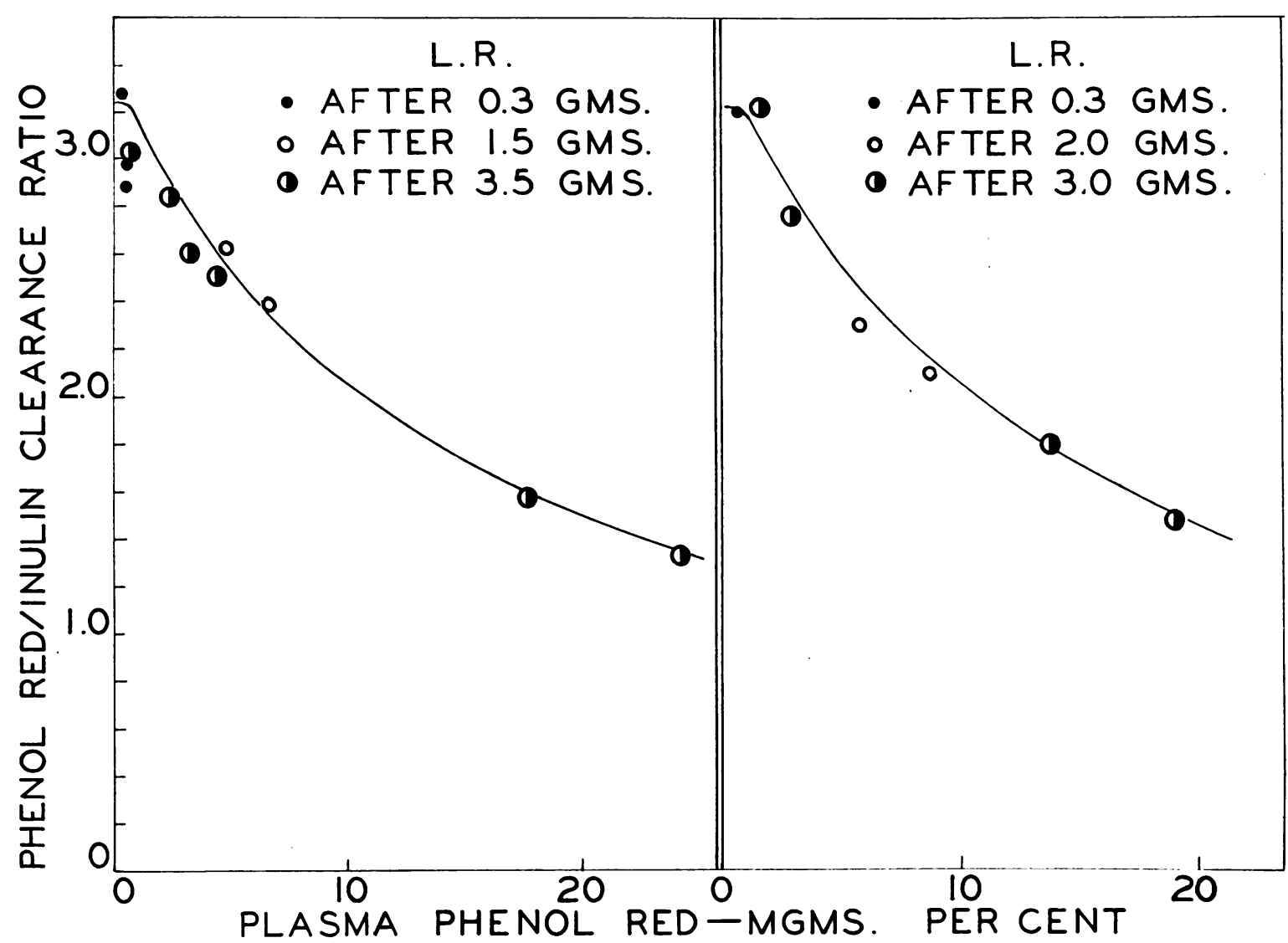

Fig. 4. Observations Showing that the Reduction oi the Phenol Red Clearance Effected by Increasing the Concentration of the Dye in the Plasma is Reversible.

Clearances were determined ( $a$ ) after a small dose of dye, (b) after an intermediate dose, (c) after a large one, and lastly $(d)$ after the plasma level had fallen to approximately its original level again. In the observations on L. R. at the left, 75 grams of inulin were given. One minute after the infusion 0.3 gram of phenol red was injected intravenously; the bladder was emptied (discard) at 27 minutes, and again at 37 and 46 minutes, and blood samples were withdrawn at 32 and 41 minutes; 1.5 grams of phenol red were injected at 49 minutes; the bladder was emptied (discard) at 68 minutes, and again at 76 and 86 minutes, and blood samples were withdrawn at 72 and 81 minutes; 3.5 grams of phenol red were injected at 89 minutes; the bladder was again emptied (discard) at 110 minutes, and at 121 and 135 minutes, and blood samples were withdrawn at 115 and 127 minutes. From 140 to 160 minutes, an additional 50 grams of inulin were given to restore the plasma level of this substance, and three urine collection periods were made between 180, 194, 207 and 220 minutes, blood samples being withdrawn at 186, 199 and 213 minutes. Further urine collection periods were made between 274 , 285 and 295 minutes, with blood samples at 279 and 290 minutes.

plasma, it follows that the dye excreted in the urine in any interval of time must be derived from this fluid and not from whole blood. For example, for one milligram to be excreted in a given time, at least $100 \mathrm{cc}$. of plasma having a concentration of $1 \mathrm{mgm}$. per cent, or $175 \mathrm{cc}$. of whole blood, having a concentration of $0.57 \mathrm{mgm}$. per cent (taking the hematocrit as 0.43 ), will be required. Since we may safely assume that the human kidney does not synthesize phenol red, the fact that in normal man the plasma clearance averages 400 cc. per minute requires, therefore, an average blood flow of at least $700 \mathrm{cc}$. per minute. Whether the blood flow is larger than this, or how much larger it may be, will depend upon whether any dye is destroyed by the kidney, and upon the degree to which the extraction of the dye from the arterial blood passing through this organ, and its concurrent excretion in the urine, approaches completion. There is no evidence 
that phenol red is destroyed by the kidney, although the recovery of injected dye in the urine is not 100 per cent because of slight excretion in the bile. From anatomical considerations it seems improbable that all the arterial blood supplied to the kidney could go to secretory tissue; excluding this fraction, which we may designate as the noneffective blood flow, we may speak of the effective blood flow as that quantity which is in fact presented to secretory tissue; the value of this effective blood flow will be given by the clearance of any substance which is not synthesized or destroyed by the kidney, but which is removed completely from this blood in one circulation (by a combination of filtration and secretion, or by secretion alone) and transferred concurrently to the urine. To what extent the human kidney completely removes the phenol red from the renal blood, it is impossible to say from the present data, although the total blood flow through the two human kidneys cannot be greatly above the average whole blood phenol red clearance (about 700 cc. per minute). Van Slyke, Rhoads, Hiller and Alving (1934) found that the urea clearance in normal unanesthetized dogs was on the average 10.5 per cent of the renal blood flow; with an average urea clearance of $75 \mathrm{cc}$. per minute in man, a corresponding efficiency would indicate a blood flow of $715 \mathrm{cc}$. per minute. Under the approximately basal conditions obtaining during these observations the cardiac output is probably not over 4.0 liters per minute (Grollman (1932)), and it is doubtful if more than one quarter of this blood could go to the two kidneys. The above considerations are of interest, therefore, in pointing to a new significance to be attached to such clearances as the phenol red clearance at low plasma levels : they open the possibility of measuring by the clearance method the blood flow or some large, physiologically constant fraction thereof, through the intact normal human kidney.

\section{SUM MARY}

In normal men the phenol red clearance is considerably in excess of the simultaneous inulin clearance. The phenol red/inulin clearance ratio is essentially constant at plasma levels of the dye below $1.0 \mathrm{mgm}$. per cent, and averages 3.2. As the concentration of dye in the plasma is increased, the absolute phenol red clearance is depressed, as is also the phenol red/inulin clearance ratio (the inulin clearance remaining unaffected).

Phenol red is bound by proteins in human plasma, and thus rendered unavailable for filtration, the fraction of free phenol red varying with the absolute concentration of the dye. It is estimated that under the conditions examined here (as also under the conditions of the standard phenol red test) not over 6 per cent of the excreted dye is excreted by glomerular filtration.

Phenol red, when added to human blood, is confined to the plasma. It is pointed out that to effect the phenol red clearance observed at low plasma levels (400 cc. per minute) a blood flow of at least $700 \mathrm{cc}$. per minute is required.

We are indebted to Miss Catherine Welsh for technical assistance in the conduct of this investigation.

\section{BIBLIOGRAPHY}

Folin, O., Two revised copper methods for blood sugar determination. J. Biol. Chem., 1929, 82, 83.

Grollman, A., The combination of phenol red and proteins. J. Biol. Chem., 1925, 64, 141.

Grollman, A., The Cardiac Output of Man in Health and Disease. C. C. Thomas, Baltimore, 1932.

MacKay, E. M., Use of phenol red in the Addis test of renal function. Proc. Soc. Exper. Biol. and Med., 1930, 27, 1039.

Marshall, E. K., Jr., The secretion of phenol red by the mammalian kidney. Am. J. Physiol., 1931-32, 99, 77.

Richards, A. N., and Walker, A. M., Quantitative studies of the glomerular elimination of phenol red and indigo carmine in frogs. J. Biol. Chem., 1930, 87, 479.

Rowntree, L. G., and Geraghty, J. T., The phthalein test. An experimental and clinical study of phenolsulphonephthalein in relation to renal function in health and disease. Arch. Int. Med., 1912, 9, 284.

Shannon, J. A., and Smith, H. W., The excretion of inulin, xylose and urea by normal and phlorizinized man. J. Clin. Invest., 1935, 14, 393.

Shannon, J. A., The excretion of phenol red by the dog. Am. J. Physiol., 1935, 113, 602.

Somogyi, M., The use of copper and iro. salts for the deproteinization of blood. J. Biol. Chem., 1931, 90, 725.

Van Slyke, D. D., Rhoads, C. P., Hiller, A., and Alving, A. S., Relationships between urea excretion, renal blood flow, renal oxygen consumption, and diuresis. The mechanism of urea excretion. Am. J. Physiol., 1934, 109, 336. 